\title{
GAMBARAN PENGETAHUAN IBU BALITA MENGENAI DIARE DI DESA BUNGAYA KECAMATAN BEBANDEM KABUPATEN KARANGASEM OKTOBER 2013
}

\author{
Hafiz Bin Hamdan \\ Fakultas Kedokteran Universitas Udayana \\ (hafizhamdan08@gmail.com)
}

\begin{abstract}
ABSTRAK
Diare merupakan masalah kesehatan masyarakat dan masih tergolong salah satu dari sepuluh penyakit penyebab kematian di Indonesia. Pada tahun 2007 terdapat kejadian luar biasa (KLB) pada bulan Februari-Maret 2007 di Kabupaten Karangasem, dimana tercatat insiden diare sebesar 574 kasus, dan jumlah kematian warga penderita diare sebanyak 6 orang. Penelitian ini bertujuan untuk mengukur gambaran pengetahuan ibu balita mengenai diare di Desa Bungaya.

Penelitian ini dilakukan pada bulan oktober 2013 dengan menggunakan rancangan cross-sectional deskriptif. Data diperoleh dari wawancara berstruktur dengan kuisioner. Responden penelitian ditargetkan 50 ibu yang memiliki balita di Desa Bungaya yang dipilih secara simple random sampling. Data yang diperoleh di analisis menggunakan program SPSS 16.0 dan disajikan dalam bentuk tabel dan narasi.

Berdasarkan analisis dan pembahasan ditemukan kejadian diare pada Balita di Desa Bungaya, yaitu sebesar $80 \%$. Dari faktor risiko yang diteliti, didapati $52 \%$ responden mempunyai pengetahuan kurang tentang diare.
\end{abstract}

Kata kunci: Diare, Balita, Pengetahuan, Sikap, Perilaku, Desa Bungaya

Pendahuluan

Penyakit diare tergolong sebagai salah satu masalah kesehatan utama di dunia dan menyebabkan sebanyak 1,5 milyar episode dan 4 juta kematian pada anak-anak di negara berkembang. Menurut data World Health Organization (WHO) pada tahun 2004, diare adalah penyebab nomor satu kematian balita di dunia. Bahkan, UNICEF melaporkan setiap detik satu anak meninggal karena diare. Hal ini banyak terjadi di negara-negara berkembang seperti Indonesia karena buruknya perilaku higiene perorangan dan sanitasi masyarakat yang dipengaruhi oleh rendahnya tingkat sosial, ekonomi dan pendidikan (Novick and Marr, 2003).

Diare masih tetap potensial berkembang di Indonesia sebagai masalah kesehatan masyarakat. Data terakhir dari Departemen Kesehatan menunjukkan bahwa diare menjadi penyakit pembunuh kedua bayi di bawah 5 tahun (balita) di Indonesia setelah radang paru atau pneumonia. Walaupun angka kematian akibat diare cenderung sudah menurun (Riskesdas 2007), tetapi kejadian diare, terutama yang menyerang Balita di daerah pedesaan, cenderung masih tetap dominan (survei Depkes tahun 2005 dan 2007). Sebagian besar Puskesmas di Propinsi Bali masih mencatat diare sebagai salah satu dari sepuluh penyakit terbesar. Tingginya kejadian diare perlu diantisipasi dengan lebih mengefektifkan kerjasama lintas program dan lintas sektor.

Tahun 2012, diare termasuk ke dalam 10 besar penyakit di Kabupaten Karangasem, Provinsi Bali di mana telah terjadi peningkatan morbiditas diare secara signifikan. Berdasarkan profil kesehatan Kabupaten Karangasem, IR diare meningkat dari 18,64/1000 penduduk tahun 2009 dan 20,06/1000 penduduk tahun 2010, menjadi 51,03/1000 penduduk pada tahun 2011. Pada tahun 2012, terjadi penurunan insiden rate diare menjadi 40,70/1000 penduduk. Sebesar 55\% dari 18.722 kasus yang tercatat merupakan kasus diare pada balita.

Pada tahun 2007 terdapat kejadian luar biasa diare (KLB) pada bulan Februari-Maret di Kabupaten Karangasem, dimana tercatat insiden diare sebesar 574 kasus, dan jumlah kematian warga penderita diare sebanyak 6 orang. Jumlah penderita diare tersebut terutama disumbang oleh Kecamatan Selat dan Kecamatan Bebandem.

Berdasarkan pengkajian di wilayah kerja Puskesmas Bebandem, Kecamatan Bebandem, Kabupaten Karangasem, jumlah balita diare mengalami peningkatan dari 188 balita tahun 2010 dan 231 balita tahun 2011 menjadi 238 balita pada tahun 2012 (Gambar 1). 


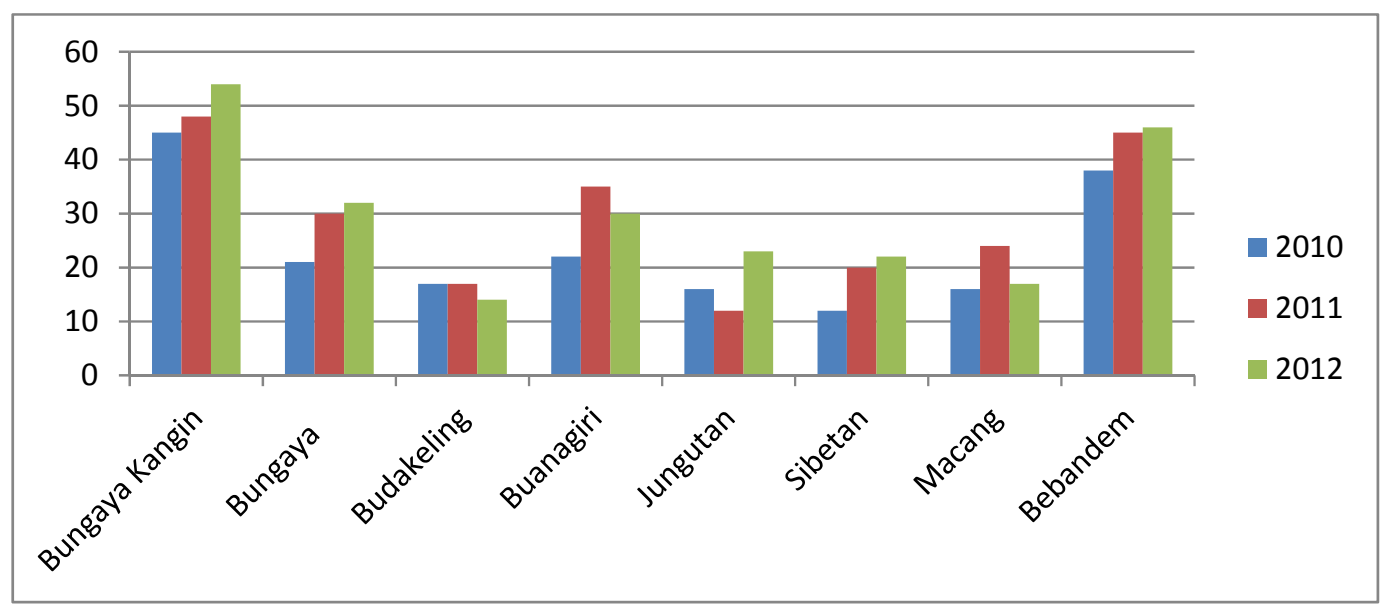

Gambar 1 Jumlah Balita Diare berdasarkan desa di wilayah kerja Pukesmas Bebandem tahun 2010 s.d. 2012

Sepanjang bulan Januari - Agustus 2013, tercatat telah terjadi 171 kasus diare pada balita. Dimana kasus terbanyak diare sepanjang bulan Januari-Agustus pada balita terjadi di Desa Bungaya. Berdasarkan hal ini, penulis tertarik untuk melakukan penelitian mengenai gambaran pengetahuan, sikap dan perilaku ibu mengenai diare pada balita di Desa Bungaya Kecamatan Bebandem Kabupaten Karangasem Oktober 2013.

\section{METODE PENELITIAN}

Penelitian ini menggunakan rancangan penelitian deskriptif, dengan metode cross sectional untuk mengetahui gambaran pengetahuan ibu balita mengenai diare di Desa Bungaya Kecamatan Bebandem Kabupaten Karangasem pada Bulan Oktober 2013. Populasi dalam penelitian ini adalah semua ibu yang memiliki balita (usia 1-5 tahun) di Desa Bungaya Kecamatan Bebandem Kabupaten Karangasem. Pemilihan sampel diawali dengan pemilihan desa dengan kasus diare terbanyak dalam 6 bulan terakhir, yaitu Desa Bungaya. Kemudian akan dipilih dua banjar dengan cara simple random sampling. Kemudian dari banjar akan dipilih ibu balita dengan mempertimbangkan kriteria inklusi dan eksklusi.

Sampel dalam penelitian ini adalah ibu yang memiliki balita, dengan persyaratan ibu yang memiliki balita (usia 1-5 tahun) yang berdomisili di Desa Bungaya Kecamatan Bebandem, Kabupaten Karangasem, Provinsi Bali dan bersedia menjadi responden. Kriteria eksklusi merupakan ibu balita yang tidak mampu diwawancarai disebabkan kondisi medis umum yang berat dan mereka yang menolak untuk mengikuti penelitian ini. Perkara yanag dinilai dari pengetahuan ibu adalah tentang pengertian, penyebab, pencegahan dan penanganan awal diare. Kategori pengetahuan tentang pengertian diare yang cukup adalah dapat menjawab pengertian diare dengan benar tanpa probing.Kategori pengetahuan tentang penyebab diare yang cukup adalah dapat menjawab minimal satu penyebab diare dengan benar tanpa probing. Kategori pengetahuan tentang pencegah diare yang cukup adalah dapat menjawab minimal satu cara pencegahan diare dengan benar tanpa probing. Kategori penanganan awal tentang diare yang cukup minimal dapat menjawab cara pengangan awal untuk diare dengan benar tanpa probing. Kategori pengetahuan tentang diare yang cukup diperoleh dengan sistem scoring, dimana nilai diatas rata-rata responden dikategorikan sebagai pengetahuan cukup, sedangkan apabila mendapat nilai dibawah nilai rata-rata dikategorikan pengetahuan tentang diare yang kurang.

Peneliti menetapkan besar sampel dalam penelitian ini adalah 50 orang setelah dilakukan perhitungan jumlah sampel berdasarkan perhitungan studi cross-sectional. Penambahan jumlah sampel ini dilakukan untuk mengantisipasi jika ada yang drop out.

\section{HASIL PENELITIAN}

\section{Karakteristik Responden}

Penelitian ini dilakukan terhadap 50 ibu balita dan semuanya dapat tercakup dalam penelitian. Karakteristik responden berdasarkan umur (40\%) responden penelitian ini berusia 25-30 tahun, $36 \%$ berusia 31-35 tahun, 18\% berusia 35-40 tahun dan $6 \%$ berusia lebih dari 41 tahun. Berdasarkan pendidikan lebih dari setengah responden berpendidikan SD (58\%), SMP (22\%), SMA (8\%), perguruan tinggi (8\%), dan ditemukan juga responden yang tidak menuntaskan pendidikan sekolah dasar (4\%). Sedangkan berdasarkan pekerjaan dalam penelitian ini didapatkan hampir sebagian besar responden bekerja (84\%) dan yang tidak bekerja sebesar (16\%)(Tabel 1).

\begin{tabular}{|lll|}
\hline No & Karakteristik & Frekuensi \% \\
(Umur,Pendidikan dan & \\
Pekerjaan) & \\
\hline
\end{tabular}




\begin{tabular}{|c|c|c|c|}
\hline \multirow[t]{4}{*}{1} & $25-30$ & 20 & 40 \\
\hline & $31-35$ & 18 & 36 \\
\hline & $36-40$ & 9 & 18 \\
\hline & $>41$ & 3 & 6 \\
\hline \multirow[t]{5}{*}{2} & Tidak sekolah/SD & 2 & 4 \\
\hline & SD & 29 & 58 \\
\hline & SLTP/sedarjat & 11 & 22 \\
\hline & SMA/sedarjat & 4 & 8 \\
\hline & Universitas & 4 & 8 \\
\hline \multirow[t]{2}{*}{3} & Bekerja & 8 & 16 \\
\hline & Tidak Berkerja & 42 & 84 \\
\hline
\end{tabular}

Tabel 1 Karakteristik Responden

\section{Kejadian Diare}

Dari wawancara terhadap responden diperoleh informasi bahwa $80 \%$ responden mengatakan balitanya pernah mengalami diare, dimana dalam kurun waktu 2 tahun sampai 6 bulan terakhir didapatkan kasus terbanyak balita mengalami diare(Tabel 2).

\begin{tabular}{|lcc|}
\hline $\begin{array}{c}\text { Waktu } \\
\text { Kejadian } \\
\text { Diare }\end{array}$ & Frekuensi & $\%$ \\
\hline$<6$ bulan & 8 & 16 \\
\hline 6-2 tahun & 23 & 46 \\
\hline 3-5tahun & 9 & 18 \\
\hline
\end{tabular}

Tabel 2 Kejadian Diare

\section{Pengetahuan Ibu}

Pengetahuan ibu diperoleh melalui wawancara dengan menanyakan tentang pengertian diare, penyebab diare, pencegahan diare, dan penanganan awal diare. Dari data yang diperoleh kemudian dilakukan skoring, dimana setiap jawaban benar diberikan skor 1 dan tidak benar diberikan skor 0 . Kemudian skor tersebut dirata-ratakan sehingga diperoleh nilai rata-rata adalah 2. Dimana skor lebih dari 2 menunjukkan pengetahuan ibu yang cukup sedangkan <2 dikatakan sebagai pengetahuan yang kurang.

\begin{tabular}{|l|l|l|l|}
\hline \multirow{2}{*}{$\begin{array}{l}\text { Pengetahuan } \\
\text { tentang diare }\end{array}$} & \multicolumn{2}{|l|}{$\begin{array}{l}\text { Pernah } \\
\text { Diare }\end{array}$} & \multicolumn{2}{|c|}{ Menderita } & \multirow{2}{*}{ Total } \\
\cline { 2 - 3 } & Ya & Tidak & \\
\hline - Cukup & $16(66 \%)$ & $8(34 \%)$ & $24(100 \%)$ \\
\hline - Kurang & $23(88 \%)$ & $3(12 \%)$ & $26(100 \%)$ \\
\hline Total & 39 & 11 & 50 \\
\hline
\end{tabular}

Tabel 3 Pengetahuan Ibu mengenai diare

Dari hasil penelitian ini diperoleh bahwa pengetahuan ibu balita mengenai diare memiliki kecenderungan terhadap kejadian diare pada balita. Dimana ibu dengan pengetahuan yang kurang, balitanya lebih banyak yang pernah mengalami diare dibandingkan dengan ibu yang memiliki pengetahuan yang cukup. Hampir seluruh ibu yang memiliki pengetahuan kurang balitanya pernah mengalami diare(Tabel 3).

\section{PEMBAHASAN}

Setelah dilakukan penelitian dan proses pengolahan data kami mendapatkan bahwa lebih banyak ibu balita yang menjadi responden anaknya pernah menderita diare. Jumlah $80 \%$ merupakan angka yang cukup besar dan bermakna, dimana hal ini menunjukkan bahwa faktor risiko diare masih sangat tinggi di wilayah Desa Bungaya. Jika dibandingkan dengan angka perkiraan kejadian diare yang ditetapkan oleh Dinas Kesehatan sebanyak 42,3\% jumlah penduduk. Tingginya kejadian diare ini perlu ditanggapi dengan menganalisis faktor-faktor risiko diare yang terdapat di Desa Bungaya. Pada penelitian ini kami mengkaji faktor resiko diare yang meliputi faktor pengetahuan, sikap dan perilaku ibu balita.

\section{Gambaran Pengetahuan Ibu Mengenai Diare}

Menurut Notoatmodjo, pengetahuan merupakan hal yang sangat penting untuk terbentuknya tindakan seseorang. Pengetahuan diperlukan sebagai dukungan dalam menumbuhkan rasa percaya diri maupun sikap dan perilaku setiap hari, sehingga dapat dikatakan bahwa pengetahuan merupakan fakta yang mendukung tindakan seseorang Tanpa pengetahuan seseorang tidak mempunyai dasar untuk mengambil keputusan dan menentukan tindakan terhadap masalah yang dihadapi. Pengetahuan ini juga mempunyai implikasi kuat dengan sikap dan perilaku seseorang. Dengan bekal pengetahuan yang cukup barulah seorang ibu dapat menerapkan cara perawatan balita yang bersih dan sehat serta menghindarkan dari berbagai risiko terjadinya diare.

Dari 50 orang responden yang diwawancara, diketahui bahwa lebih banyak ibu balita yang memiliki pengetahuan kurang dibandingkan yang memiliki pengetahuan cukup. Namun, jumlah antara ibu balita yang berpengetahuan kurang dan cukup tidak terlalu berbeda jauh, dimana terdapat 26 ibu balita yang berpengetahuan kurang dan 24 yang berpengetahuan cukup. Jika dilihat dari hasil penelitian ini, didapatkan bahwa balita yang berasal dari ibu dengan pengetahuan kurang memiliki kecendrungan untuk menderita diare. Akan tetapi, pada balita yang berasal dari ibu yang memiliki pengetahuan cukup juga pernah ditemukan kejadian diare. Hal ini bisa disebabkan karena faktor lain seperti perilaku ibu yang kurang baik, karena pengetahuan yang cukup masih belum dapat mengubah perilaku seseorang (Malikhah, 2009).

Namun jika dilihat dari persentase, terlihat lebih banyak kejadian diare pada kelompok responden dengan pengetahuan kurang dibandingkan dengan kelompok berpengetahuan cukup. Hal ini sesuai dengan hasil 
penelitian sebelumnya yang dilakukan oleh Notoatmojo dan didukung oleh beberapa penelitian lain yang menyatakan bahwa pengetahuan ibu yang rendah berpengaruh pada kejadian diare pada balita (Fatmasari, 2008; Warman, 2008; Kasman, 2003).

\section{DAFTAR PUSTAKA}

1. Departemen Kesehatan R I. 2007. Pedoman Pemberantasan Penyakit Diare Edisi Ketiga. Ditjen PPM dan PL. Jakarta.

2. Departemen Kesehatan R I. 2009, Buku Pedoman Pengendalian Penyakit Diare, Departemen Kesehatan RI, Jakarta.

3. Fatmasari, Heni. 2008. Hubungan Beberapa Faktor Risiko dengan Kejadian Diare Pada Anak Balita di Ruang Rawat Inap Puskesmas Kecamatan Jatibarang Kabupaten Brebes Tahun 2008. Diakses tanggal 23 September 2013.

4. Gunung, I. K. 2003. Langkah-Langkah Penelitian Ilmiah dan Pembuatan Kuesioner, Lab IKK-IKP Fakultas Kedokteran Universitas Udayana, Denpasar.

5. Hung, B.V. 2006. The Most Common Causes and Risk Factors for Diarrhea Among children less than five years of age admitted to Dong Anh Hospital Hanoi, Northern Vietnam. Diakses pada tanggal 20 September 2013.

6. Kasman. 2003. Faktor-Faktor yang Berhubungan dengan Kejadian Diare pada Balita di Puskesmas Air Dingin Kecamatan Koto Tangah Kota Padang Sumatera Barat Tahun 2003. Diakses tanggal 20 September 2013.

7. Kusumawati, dkk. 2012. Hubungan Perilaku Hidup Bersih dan Sehat dengan Kejadian Diare pada Balita Usia 1-3 Tahun : Studi Kasus di Desa Togowanu Wetan, Kecamatan Togowanu Grobogan. Semarang : POLTEKKES KEMENKES Semarang. Diakses tanggal 20 September 2013.

8. Malikhah. 2009. Gambaran Pengetahuan dan Sikap Ibu dalam Pencegahan dan Penanggulangan Secara Dini Kejadian Diare pada Balita di Desa Hegarmanah Jatinagor. Diakses tanggal 23 September 2013.

9. Menteri Kesehatan Republik Indonesia. 2008. Laporan Riskesdas 2007 Provinsi Bali. Badan Penelitian dan Pengembangan Kesehatan. Departemen Kesehatan RI.

10. Nilton, dkk. 2008. Faktor-Faktor Sanitasi Yang Berpengaruh Terhadap Timbulnya Penyakit Diare di Desa Klopo Sepuluh Kecamatan Sukodono Kabupaten Sidoarjo. Diakses tanggal 20 September 2013.

11. Notoatmodjo, S. 2003. Ilmu Kesehatan Masyarakat. Jakarta: Rineka Cipta.

12. Sarudji, D. 2006. Kesehatan Lingkungan. Karya Putra Darwati. Bandung.
13. Sarwono. 2009. Prinsip Dasar Ilmu Perilaku. Rineka Cipta. Jakarta. 